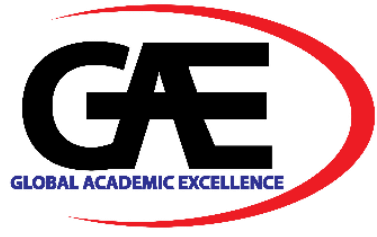

\title{
A PRELIMINARY STUDY TOWARDS DESIGNING A COMPUTATIONAL THINKING SKILLS BASED MODEL FOR THE DESIGN AND TECHNOLOGY IN PRIMARY SCHOOLS
}

\author{
Rahimah Ismail $^{1 *}$, Azlina Ahmad ${ }^{2}$, Halimah Badioze Zaman ${ }^{3}$ \\ 1 Institute of IR4.0, Universiti Kebangsaan Malaysia, Selangor, Malaysia. \\ Email: p102140@siswa.ukm.edu.my \\ 2 Institute of IR4.0, Universiti Kebangsaan Malaysia, Selangor, Malaysia \\ Email: azlinaivi@ukm.edu.my \\ 3 Institute of Informatics and Computing (IICE), Universiti Tenaga Malaysia (UNITEN), Putrajaya, Malaysia \\ Email: hbzivi@gmail.com \\ * $\quad$ Corresponding Author
}

\section{Article Info:}

Article history:

Received date: 10.06 .2021

Revised date: 15.07 .2021

Accepted date: 20.08 .2021

Published date: 01.09.2021

\section{To cite this document:}

Ismail, R., Ahmad, A., \& Zaman, H B. (2021). A Preliminary Study Towards Designing a Computational Thinking Skills Based Model for The Design and Technology Subject in Primary Schools. Journal of Information System and Technology Management, 6 (22), 115-127.

DOI: $10.35631 / J I S T M .622010$

This work is licensed under CC BY 4.0

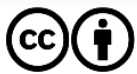

Abstract:

21 st century learning requires students to master a variety of future skills. This is important to increase their creativity and ability in solving problems systematically and creatively both in learning and in daily life. In improving thinking and problem-solving skills, Computational Thinking (CT) skills are important skills that need to be mastered by students. They are applicable not only in computer science but can also be applied in various other fields, especially Science, Technology, Engineering, and Mathematics (STEM). A preliminary study was conducted to identify the requirements to develop a model based on CT skills across STEM for the subject Design and Technology (RBT) in primary school. Results of the preliminary study show that the inability of students to think creatively and solve problems systematically is a contributing factor to problems faced by students in the Project Development part of RBT Year 5. This study explored RBT learning from the perspective of teachers and students. A survey was conducted using an instrument developed to further explore the problems faced by primary school students in the Project Development part of the RBT subject. Data of the survey were analysed using the Statistical Package for Social Science (SPSS) software, version 23.0, for data descriptions.

Keywords:

Needs Analysis, Design and Technology, Computational Thinking Skills 


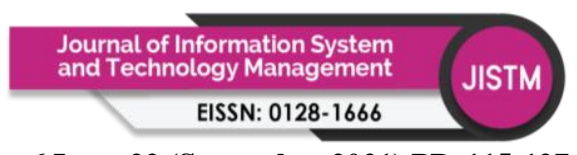

Volume 6 Issue 22 (September 2021) PP. 115-127 DOI: 10.35631/JISTM.622010

\section{Introduction}

Effective teaching and learning allows students to explore learning through a fun experience whilst equipping them with a variety of important skills and digital technologies in preparation for the future needs in the era of Industrial Revolution 4.0 and digital economy. The ability of students to solve a problem systematically, creatively, and innovatively requires a proactive and effective strategy. The ability of students to think critically using high-level thinking, intelligently and consistently is able to position them as students who are able to face the challenges of the $21^{\text {st }}$ century. Future generations need to master a range of skills for them to be relevant to meet future needs. $21^{\text {st }}$ century learning, requires a shift to a more dynamic, creative, and agile approach to learning, as well as in line with today's digital technological developments. This matter is stated as a priority in the Malaysian Education Development Plan (PPPM 2015-2025), where students need to master five (5) main components in mastering learning, namely: communication, collaboration, critical thinking, creativity, and values; also known as $4 \mathrm{~K} 1 \mathrm{~N}$. Intense competition in careers requires a new generation to be skilled in problem management and possess creative thinking skills rather than excel from a purely academic aspect. The ability to think creatively and solve problems systematically is able to lead students towards more positive development.

In Malaysia, the subject of Design and Technology or RBT, was introduced in primary schools since the beginning of the year 2014 to provide students with knowledge, skills, and values relevant to the challenges of the $21^{\text {st }}$ century and the $4^{\text {th }}$ Industrial Revolution. The RBT curriculum emphasizes on knowledge, skills, and work steps for the production of a project with the aim of providing exposure to aspects of problem solving, generating ideas, designing, and knowing how to use current materials and technologies whilst developing a project to produce an innovative product. However, at the primary school level, the emphasis on thinking skills and problem-solving skills is less emphasized with the assumption that primary school students are still in their early stages. Teacher centered learning and over-reliance on existing learning aids limits students' creative thinking and problem-solving abilities.

The preliminary study phase is conducted to identify problems that exist among the selected population (target population). This process also involves the process of identifying the best solution that can be taken by the researcher (Witkin \& Altschuld 2001). This phase is also more focused on what should be done than what has already been done (Riviere 1996). Therefore, this phase is an important phase for researchers to identify problems that arise in RBT learning in assessing thinking ability and problem solving in the need to develop a learning model based on Computational Thinking (CT) skills across STEM in RBT learning in primary schools especially in activities project development.

\section{Literature Review}

The results of the study conducted, which was related to problem-solving ability and thinking skills among school children, whether at primary, secondary, and tertiary levels, still show low achievement. Highlights of past studies show that today's students are still weak in thinking skills and problem-solving skills systematically, creatively, and critically. Although various efforts have been made to address this problem, it has yet to show impressive results. In a study Hadi et al. (2018) found that students who excel in academics are not necessarily able to solve a given problem systematically and effectively. Even other studies have also shown that many 
students are less able to solve open-ended problems because they do not have creative and innovative thinking skills (Hurd, P 2018; Hadi, S.A. et al 2018; Norzari, A.Y. \& Saimin 2014), as shown in Table 1.

Table 1: Past Studies Related to Pupils' Disabilities in Thinking and Problem-Solving Skills

\begin{tabular}{|c|c|c|c|}
\hline No. & Research & $\begin{array}{c}\text { Inability of learners in } \\
\text { thinking }\end{array}$ & Plausible Solution \\
\hline 1 & $\begin{array}{l}\text { Hadi, S.A. et al. } \\
2018\end{array}$ & $\begin{array}{l}\text { Inability to think critically } \\
\text { and logically }\end{array}$ & $\begin{array}{l}\text { Free Inquiry Model; ability to } \\
\text { think independently }\end{array}$ \\
\hline 2 & Hurd, P. 2018 & $\begin{array}{l}\text { Inability to see the relation } \\
\text { between critical thinking, } \\
\text { innovative thinking, } \\
\text { creativity, problem solving, } \\
\text { decision making and } \\
\text { communication }\end{array}$ & $\begin{array}{l}\text { Substantive and non- } \\
\text { substantive concepts of critical } \\
\text { thinking }\end{array}$ \\
\hline 3 & $\begin{array}{l}\text { Foster, J. \& } \\
\text { Yaoyuneyong, G. } \\
2016\end{array}$ & $\begin{array}{l}\text { Inability to integrate } \\
\text { different disciplines to solve } \\
\text { problem innovatively }\end{array}$ & $\begin{array}{l}\text { Flipped classroom cross } \\
\text { disciplinary }(\mathrm{CD}), \text { Client- } \\
\text { based project }(\mathrm{CBP})\end{array}$ \\
\hline 4 & $\begin{array}{l}\text { Tsingos-Lucas, C. } \\
\text { et.al } 2016\end{array}$ & $\begin{array}{l}\text { Inability to think } \\
\text { reflectively and critically }\end{array}$ & $\begin{array}{l}\text { Reflective Ability Clinical } \\
\text { Assessment (RACA), was } \\
\text { introduced to enhance self-and } \\
\text { peer reflection. }\end{array}$ \\
\hline 5 & $\begin{array}{l}\text { Norzari, A.Y. \& } \\
\text { Saimian } 2014\end{array}$ & $\begin{array}{l}\text { Inability to solve problem } \\
\text { creatively }\end{array}$ & $\begin{array}{l}\text { Problem-Solving Approach- } \\
\text { Jamal Abedi Creativity Test \& } \\
\text { Torrance Creativity Test }\end{array}$ \\
\hline 6 & Sullenger, K. 2005 & $\begin{array}{l}\text { Inability to think } \\
\text { scientifically; sees science } \\
\text { as unnatural }\end{array}$ & Teaching \\
\hline
\end{tabular}

\section{Statement of Problem}

The speed at which technology has developed and the wave of change in the era of the Industrial Revolution 4.0 that combines digital, physical and biological worlds where the Internet of Things, AI, Robotics, Cloud Computing, Augmented Reality and Cyber Security meet, show that there is a need for a more agile and competent human capital specializing in these fields in the future. But technology itself is not enough, the human capital needed must be able to think scientifically and be able to solve problems. Although various efforts and approaches have been introduced to prepare human capital capable of facing these challenges, our students are seen to be still weak in thinking and problem-solving skills (Barr \& Stephenson 2011; Foster \& Yaoyuneyong 2016; Hadi et al.2018), in learning as well as in daily lives. The inability of students to solve problems systematically and the inability of students to think creatively in solving problems is increasingly evident in preparing a generation that is ready to face the challenges of the $21^{\text {st }}$ century. The need for early exposure to problem-solving skills has systematically prompted the government to introduce CT skills starting from the primary school level onwards. CT is an essential skill that $21^{\text {st }}$ century students need to master to solve the latest problems. In fact, CT is now a basic skill for everyone, not just to scientists or Copyright $\odot$ GLOBAL ACADEMIC EXCELLENCE (M) SDN BHD - All rights reserved 


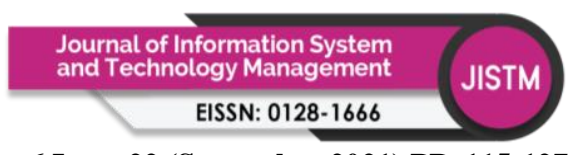

Volume 6 Issue 22 (September 2021) PP. 115-127

DOI: 10.35631/JISTM.622010

computer experts, but important to all humans and fields (Bocconi et al. 2016; Lu \& Fletcher 2009; Wing 2008; Yadav et al. 2016).

The integration of CT skills in STEM learning is able to inject the creative minds and highlevel thinking of students in an independent, collaborative, and systematic manner Chalmers 2018; Sung et al. 2017). The subject of Design and Technology is one of the subjects that involves the fields of engineering, technical, mathematics, and science. Additionally, various types of knowledge is applied in its learning. The RBT curriculum requires students to undergo theoretical and practical learning or hands-on activities. At the end of the lesson, students need to produce a useful product. The production of this product is to assess the extent of students' understanding of the learning that followed. Each title requires students to produce a different project where students have to follow each step that has been set based on the Curriculum and Assessment Standards Document (DSKP) that has been set by the Ministry of Education Malaysia (MOE). However, due to constraints and a lot of commitment to the provision of materials and equipment, most teachers prepare prefabricated materials supplied by suppliers for students to conduct the project. Students only need to produce a project based on the manual provided without having to think deeply to produce 'an innovative and useful product' creatively and systematically. Even the primary school students do not put much attention on the project production process but more on the production of the final product. These problems are among the factors contributing towards the improvement of students who are weak in thinking skills and problem-solving skills. The lack of emphasis on students' cognitive activities in learning activities makes students lazy to think, thereby making them rely entirely on teachers and existing learning aids.

Therefore, an approach that encourages students to learn independently by practicing highlevel thinking skills creatively and systematically should be applied in the teaching and learning of RBT in primary schools, especially in the process of producing products conducted as project-based, which requires students to complete projects within a certain period of time with the provision of materials and equipment. While it is limited, it allows students to conduct activities with high interest, motivation, and creativity.

\section{Objectives of the Study}

In general, the initial analytical study conducted aimed at identifying the needs to develop a learning model based on CT skills across STEM for Design and Technology (RBT) subjects, particularly in project development activities in primary schools.

\section{Methodology}

The methodology of the study conducted in the needs analysis phase is to use qualitative and quantitative approaches. McKillip (1987) stated that the analysis phase is very important in a developmental study and becomes an indicator of the value of a problem to be studied. The variety of methods used is aimed at obtaining in-depth data related to the issues studied. This research is a study conducted through surveys, interviews and observations. The survey study used in this research is a cross sectional survey that involves the distribution of questionnaires only once in a certain time period (Creswell 2012). The validity and reliability of the instrument is done first by involving three (3) experts, namely, content experts, language experts, and 
design experts. All three experts agreed to all the questions posed and there were only slight improvements to the more in-depth questions and answers to the actual research questions.

\section{Research Design}

Preliminary analytical studies used qualitative and quantitative approaches, also known as mixed method. Preliminary analytical studies involved Preliminary Analytical Study 1 (KAA1) and Preliminary Analytical Study 2 (KAA2). The study design is based on the first phase in the ADDIE model, which is the Analysis Phase. The analysis phase is conducted to identify the real problems in RBT learning, especially in the production of RBT projects on the target population. Survey questionnaires, semi-structured interviews and observations were conducted to answer the first question of the study, namely, how Design and Technology learning is implemented in the need to develop a Design and Technology Model based on Computational Thinking (CT) skills across STEM in RBT project production for elementary school students?

\section{Study Sample}

The study samples in KAA1 and KAA2 involved different numbers and students. The sample was selected based on the purpose of the study conducted and was selected randomly in the form of purposive sampling. KAA1 involved 122 students who were selected from three schools based on a number of pre-determined criteria, namely, from day national schools, urban school categories, mixed classes of boys and girls, and having different academic backgrounds. The study sample was among Year 5 students who follow RBT learning. Meanwhile, KAA2 involved four (4) students and three (3) RBT teachers. All samples involved were from selected primary schools in Putrajaya, as shown in Table 2.

Table 2: Sample of KAA1 and KAA2

\begin{tabular}{|c|c|c|c|c|}
\hline No. & Sample & \multicolumn{3}{|c|}{ Number of Respondents } \\
\hline \multirow[b]{3}{*}{1} & & \multirow{2}{*}{$\begin{array}{c}\text { KAA1 } \\
\text { Students }\end{array}$} & \multicolumn{2}{|c|}{ KAA2 } \\
\hline & & & Students & Teachers \\
\hline & School 1 (SK1) & 41 & 4 & 1 \\
\hline 2 & School 2 (SK2) & 40 & & 1 \\
\hline 3 & School 3 (SK3) & 41 & & 1 \\
\hline & Total & 122 & & 3 \\
\hline
\end{tabular}

\section{Data analysis}

In order to obtain coherent and in-depth data and answer research questions, survey methods, interviews, and observations were conducted. The survey method used a survey form as a research instrument tool. Respondents took a day to answer the distributed survey questionnaire before handing it back to the researcher. While for the interviews and observations, in-depth transcription was done on all data obtained when KAA1 and KAA2 were conducted. Descriptive data from the survey questionnaire were analyzed using Statistical Package for Social Science (SPSS) version 23.0. 


\section{Findings of the Study}

From the initial study conducted, the findings of the study were obtained from the views of teachers and students. Two studies were conducted, namely, Preliminary Analytical Study 1 (KAA1) and Preliminary Analytical Study 2 (KAA2), to answer the questions of the analysis phase study.

\section{Preliminary Analysis Study (KAA1)}

\section{Respondent Background}

Table 3 shows the findings of KAA1. A total of 122 students were involved to identify the real issues and problems that occur in RBT learning in the need to develop a Design and Technology model based on CT skills in primary schools. Overall, to look at problem-solving skills, creative thinking skills, and knowledge of CT skills, respondents only had to answer Yes or No to the questions posed.

Table 3: Demographics of Respondents

\begin{tabular}{llcc}
\hline \multicolumn{1}{c}{ Aspects } & & $\begin{array}{c}\text { Aspect } \\
\text { Number (N) }\end{array}$ & Percent (\%) \\
\hline Gender & Male & 54 & 44 \\
School Category & Female & 68 & 56 \\
& Urban & 122 & 100 \\
& Rural & - & - \\
I am good at solving problems systematically. & Yes & 42 & 34.4 \\
& No & 80 & 65.6 \\
I think deeply to solve the problem & & & \\
& Yes & 36 & 29.5 \\
I know about Computational Thinking (CT) skills. & Yes & 86 & 70.5 \\
& No & 24 & 19.7 \\
\hline
\end{tabular}

The results of the study from Table 3, the demographics of respondents involved in KAA1, showed that the number of female respondents exceeded the number of male respondents, namely $68(56 \%)$ females and $54(44 \%)$ males. Of the 122 respondents involved, $41(34 \%)$ samples were from School 1 (SK1), 40 (33\%) samples from School 2 (SK2), and 41 (33\%) samples were from School 3 (SK3). All samples consisted of primary school students in Putrajaya. 


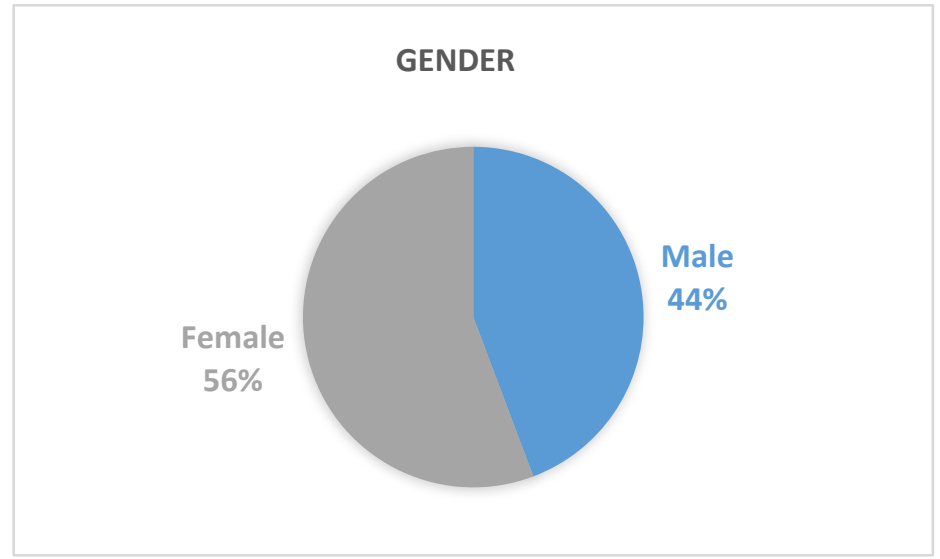

Figure 1: Gender

From the analysis made, 80(65.6\%) respondents stated No, compared to $42(34.4 \%)$ respondents who stated Yes for systematic problem-solving skills. While for the item I think deeply to solve problems, almost $86(70.5 \%)$ respondents stated that they do not think deeply to solve problems, as compared to only $36(29.5 \%)$ respondents who stated that they use deep thinking skills to solve problems. To know about the knowledge of CT skills, the findings clearly show that most students do not know and understand about these skills in general, namely 98(80.3\%) stated No, and only 24(19.7\%) stated Yes. These findings clearly show that students' systematic problem-solving skills and creative thinking skills are relatively weak, especially in the RBT project development activities carried out. This finding is in line with the literature review which states that although various efforts have been made by the government and the ministry of education to improve problem solving skills and thinking skills of students, these skills are still at a less encouraging level and do not reach the expected standards.

\section{Topic Difficulty Level}

Table 4, through a survey conducted during KAA1, clearly shows that $82(67 \%)$ respondents choose the topic of Project Development as the most difficult and less popular topic in RBT Year 5 learning. 8 (7\%) respondents chose according to level of difficulty.

Table 4: Topic Selection According to Difficulty Level for Year 5 RBT Subjects

\begin{tabular}{|c|l|c|c|c|c|c|}
\hline \multirow{2}{*}{ Bil. } & Topic RBT Year 5 & \multicolumn{3}{|c|}{ Number of Students } & Frequency & \multirow{2}{*}{ Percentage } \\
\cline { 3 - 6 } & & $\begin{array}{c}\text { School 1 } \\
\text { (SK1) }\end{array}$ & $\begin{array}{c}\text { School 2 } \\
\text { (SK2) }\end{array}$ & $\begin{array}{c}\text { School 3 } \\
\text { (SK3) }\end{array}$ & & \\
\hline 1. & Technology Basics & 5 & 7 & 8 & 20 & $16 \%$ \\
\hline 2. & Project Development & 31 & 26 & 25 & 82 & $67 \%$ \\
\hline 3. & $\begin{array}{l}\text { Agricultural } \\
\text { Technology }\end{array}$ & 3 & 5 & 4 & 12 & $10 \%$ \\
\hline 4. & Home Science & 2 & 2 & 4 & 8 & $7 \%$ \\
\hline \multicolumn{2}{|r|}{ Total Number of Students } & $\mathbf{4 1}$ & $\mathbf{4 0}$ & $\mathbf{4 1}$ & $\mathbf{1 2 2}$ & $\mathbf{1 0 0 \%}$ \\
\hline
\end{tabular}

Figure 2 shows a graph of the frequency and percentage of topic selection according to the level of difficulty among students in the Year 5 RBT topic. 


\section{Preliminary Analysis Study 2 (KAA2)}

The results of KAA2 analysis support the findings of KAA1 analysis, where interviews conducted with three (3) RBT teachers also stated that the topic of Project Development for RBT Year 5 is the most difficult topic to teach and master by students because this topic requires students to produce a useful product by combining various engineering fields such as technical, electrical and electronics, entrepreneurship, and technology. The combination of all these areas requires a systematic, creative, and innovative solution effort, taking into account the constraints of time, materials, and limited equipment. The inability of students to think creatively and the weakness of students in solving problems systematically makes this topic difficult to master and less popular with students.

\section{Teacher Interview}

The results of interviews conducted online through Zoom Meetings and Google Meetings to identify the level of difficulty in the topic of RBT Year 5 to three (3) RBT teachers as respondents of KAA2, found that all three teachers chose the Project Development topic as the most difficult topic to teach and understand by students in learning RBT Year 5. While the interview to identify the mastery of problem-solving skills and thinking skills of students in project development activities was carried out, Teacher 1(G1) and Teacher 2(G2) expressed the same opinion that these generic skills are at a moderate level and requires a more effective approach to ensure that these skills are properly mastered by the students. While Teacher 3(G3) stated that students' generic skills are still weak and need a skill that is able to encourage students to use thinking skills and problem-solving skills to the maximum extent.

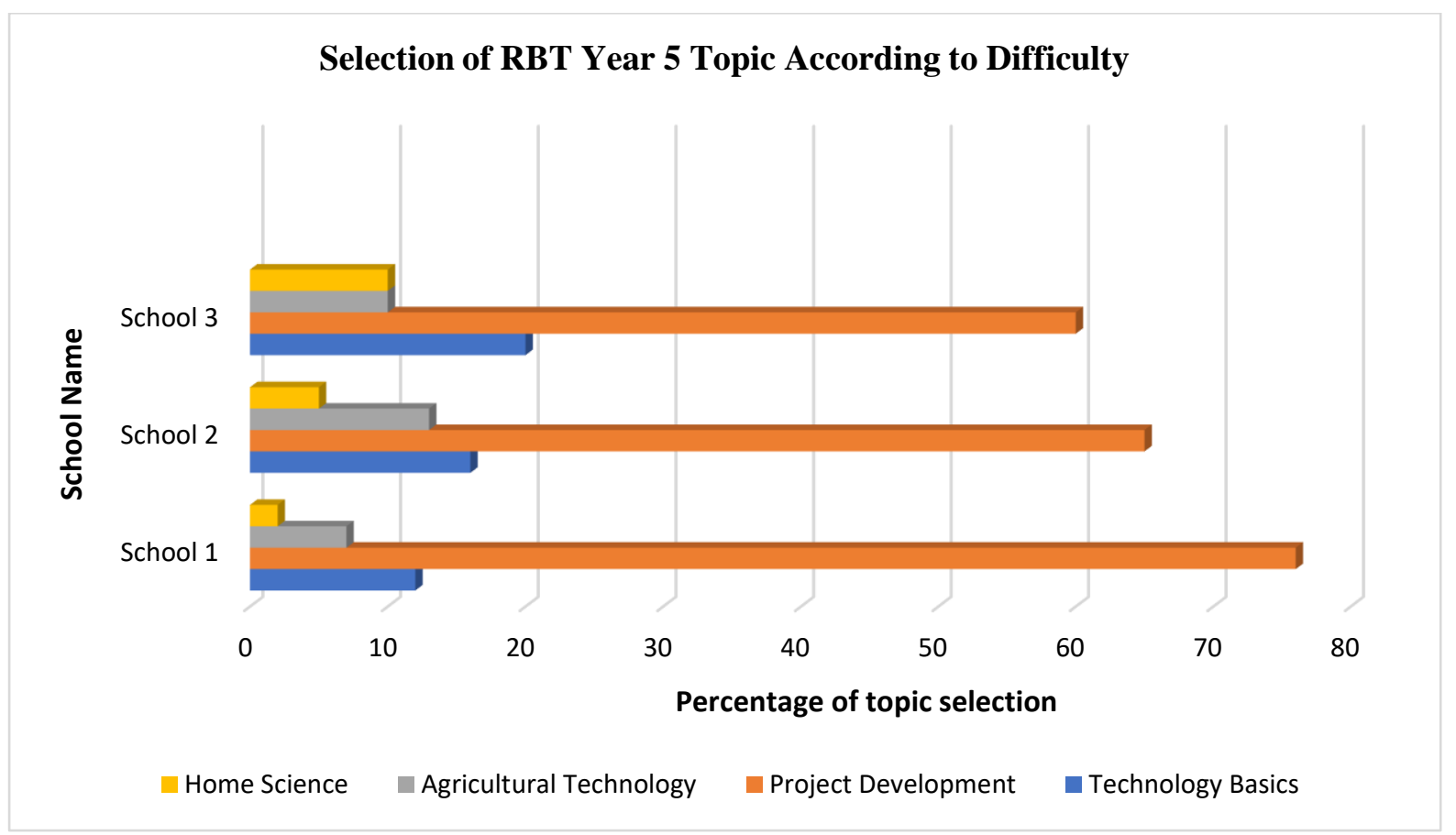

Figure 2: Percentage of Pupils and Topic Selection by Difficulty 


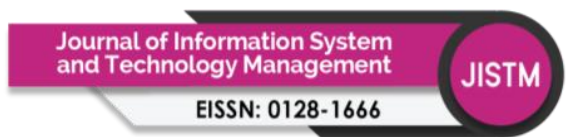

Volume 6 Issue 22 (September 2021) PP. 115-127

DOI: 10.35631/JISTM.622010

\section{Student Interview}

Semi-structured interviews were conducted for four (4) students, namely, Student 1(M1), Student 2(M2), Student 3(M3), and Student 4(M4). The results of the interviews found that all the students involved in KAA2 had fun making animal cages. Various reactions and conversations were recorded throughout the session. M1 and M4 stated that they faced problems when producing sketches because they had no ideas, and the task was less interesting. M2 stated that only after being given a brief analogy by the teacher and discussing with a friend, he had the idea to produce a sketch, because the sketches, had to be made individually. All the students stated that they had no idea on how to draw the cage according to the problems that needed to be solved. Three of them stated that due to insufficient materials and time, they produced projects that were not the same as the sketches produced. Here it can be concluded that, students do not have the ability to solve problems systematically on the grounds of insufficient time and materials. Even from the aspect of creativity, they are less creative to produce productive products that are capable of solving a given problem.

\section{Observations}

Findings of the observations conducted during the project development session show that, students M1, M2, and M4 had difficulty in finding creative ideas to produce sketches. Sketching is an important process in project development activities (Robbie et al. 2000; MRM 2017). The inability of students to think critically, innovatively, and creatively in producing sketches indicates that students are weak in thinking skills. While the inability of students to produce products that are innovative and useful to solve a given problem shows that students are not able to solve problems systematically, and effectively. Factors such as lack of existing experience also contribute to students having no idea of how to produce a good sketch or product. However, if students were given guidance or initial analogies about the basic concepts and approaches that are able to encourage their' abilities to the maximum, then surely students' abilities in thinking skills and problem-solving skills can be improved. In real life, various challenges have to be faced, and these should not be an excuse for students to be weak.

\section{Discussion}

Findings of the initial analysis study (KAA1 and KAA2) for the analysis phase that was implemented on 122 respondents in KAA1 and 4 students and 3 teachers in KAA2 at Putrajaya primary schools on the subject of RBT Year 5 learning, showed that the level of problemsolving skills and thinking skills of respondents (students) was weak. The inability of students to solve problems and produce projects in a limited period of time and constraints in terms of materials and equipment, showed that students are not able to think and solve given problems innovatively, creatively, and systematically. The frequency of No being higher than Yes indicates that the student does not know how to solve problems systematically. The inability of students to think creatively in problem solving also shows a high frequency. This situation clearly shows that the problem-solving skills and thinking skills of primary school students, especially in the development of RBT projects, are still low. This supports earlier findings that students who excel in academics are not necessarily able to solve complex problems systematically (Hadi et al. 2018). A study by Halimah Badioze Zaman et al. (2018) showed that the inability of students to think logically, creatively, scientifically, and innovatively is still 
high, and is supported by many others as well (Hurd, P 2018; Foster, J. \& Yaoyuneyong, G, 2016; Tsingos-Lucas, C. et al. 2016, Norzari, AY \& Saimian 2014; Sullenger, K. 2005).

Referring to the knowledge of CT skills, students are still less clear and less knowledgeable about CT skills as effective problem-solving skills systematically. The possibility of lack of exposure and teachers not implementing $\mathrm{CT}$ in teaching and learning are also among the factors that these skills are used less by students in problem solving. Although various efforts have been carried out by the Ministry of Education Malaysia (MOE) in collaboration with various parties such as Malaysia Digital Economy Corporation (MDEC) in collaboration with Microbit Elvira in introducing CT as a powerful skill in solving complex problems, the results are still less impressive. Students were found to be still weak in solving problems systematically. CT should be seen as a system of thinking that is capable of solving problems using certain methods and techniques and requires efforts to solve complex problems into smaller components, produce formulas, and create patterns (Ummi Hani \& Siti Fatimah Yassin 2020).

Preliminary analytical studies also show that primary school students are still weak in problem solving skills and thinking skills. In the context of STEM learning, CT needs to be mastered by teachers and students in preparation for future needs. CT is a basic skill that is important for everyone, not just for scientists or computer experts alone (Wing 2008). In the age of digital technology, the need for a skilled workforce in the use of ICT and technology is very high and more important than regular stream graduates. Graduates with ICT skills and 21st century skills have many advantages to meet future career opportunities. Students need to be exposed to a systematic, relevant, and effective skill to reduce the gap in their inability to think creatively and solve problems systematically, such as Computational Thinking (CT) skills. Our students need to exert more effort to solve problems more creatively and systematically by mastering a skill that is powerful and relevant to the learning needs of the $21^{\text {st }}$ century, further equipping them towards the needs of IR4.0. CT gives humans the advantage of solving complex and intricate problems (Voogt et al. 2015; Barr \& Stephenson 2011; Selby 2013; Zahilah et al. 2019). CT is also seen to be able to create more active, collaborative, and student-centered learning as well as educating students to the spirit of inquiry and self-learning (Lu et. al. 2009; Hadad 2019; Kong et al. 2018).

Therefore, in order to integrate CT into the STEM field, it needs to be exposed since to primary and secondary education so that $21^{\text {st }}$ century skills become ingrained in students from the very beginning (Yaday et al., 2016; 2017). Such skills are important for children to develop themselves in the $21^{\text {st }}$ century, taking into account the right learning materials and learning approaches (S Amri et al. 2019). According to Ciampa (2014), innovative and effective learning will motivate students to continue learning especially for a long period of time.

"CT involves solving problems, systems, and understanding human behavior, by describing the fundamentals of computer science. The thought process in formulating and solving problems is done in an effective way" (Wing 2008; 2011). 


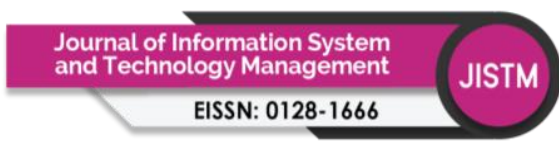

Volume 6 Issue 22 (September 2021) PP. 115-127 DOI: 10.35631/JISTM.622010

\section{Conclusion}

Overall, the findings of this needs analysis activity show the coherence and appropriateness of student and teacher respondents' agreement in exploring issues in RBT Year 5, learning to identify real problems faced by primary school students in RBT teaching and learning for Project Development. Additionally, the initial analytical study conducted was also able to take a closer look at the level of ability of primary school students in thinking skills and problemsolving skills critically, creatively, innovatively, and systematically, especially in RBT project development activities. A more effective approach that is able to improve students' systematic problem-solving skills and thinking skills so that they are more creative, needs to be implemented in primary schools and needs to be mastered by students at the beginning of school. Therefore, in conclusion, the findings of KAA clearly show the need for the development of a Design and Technology learning model based on CT skills across STEM in primary schools, especially in RBT learning for the title of Project Development Year 5. The development of a model that meets the learning needs of the $21^{\text {st }}$ century, implies that the implementation of CT skills in Project Development, especially in primary schools, needs to be developed as generic skills that need to be mastered by students in early school levels to be in line with the goals of the PPPM (2013-2025). This is also important to meet the country's transformational national agenda to produce agile, technological, scientific, innovative and creative workforces in the digital economy era with the IR4.0 landscape.

\section{References}

Altschuld, J. W., \& Witkin, B. R. (2000). From Needs Assessment to Action: Transforming Needs into Solution Strategies. Sage Publications: Thousand Oaks, CA.

Ummi Hani Mohd Asarani \& Siti Fatimah Mohd Yassin. (2020). Pengintegrasian Pemikiran Komputasional Dalam Aktiviti Pengaturcaraan dan Robotik. International Journal of Education and Pedagogy 2(2): 126-135

Barr, V. \& Stephenson, C. (2011). Bringing Computational Thinking To K-12: What Is Involved and What Is the Role of The Computer Science Education Community? ACM Inroads 2(1): 48-54

Bocconi, S., Chioccariello, A., Dettori, G., Ferrari, A., Engelhardt, K., Kampylis, P. \& Punie, Y. (2016). Developing Computational Thinking in Compulsory Education-Implications for Policy and Practice. Joint Research Centre (JRC)

Chalmers, C. (2018). Robotics And Computational Thinking in Primary School. International Journal of Child-Computer Interaction 17: 93-100. https://doi.org/10.1016/j.ijcci.2018.06.005.

Ciampa, K. (2014). Learning In a Mobile Age: An Investigation of Student Motivation. Journal of Computer Assisted Learning, 30(1), 82-96.

Foster, J. \& Yaoyuneyong, G. (2016). Teaching innovation: Equipping Students to Avercome Real-World Challenges. Higher Education Pedagogies 1(1):42-56

Hadad, R. \& Lawless, K.A. (2014.) Assessing Computational Thinking. Encyclopedia of Information Science and Technology, Third Edition 1568-1578.

Hadi, S.A., Susantini, E. \& Agustini, R. (2018.) Training of Students' Critical Thinking Skills Through the Implementation of a Modified Free Inquiry Modle. Journal of Physics: Conference Series 947(1)

Halimah Badioze Zaman, Azlina Ahmad, Aliimran Nordin, Hamidah Yamat@ Ahmad, Aliza,A., Ang, M.C., Azwan Shaiza, N., Riza S., Normazidah C.M., Aziziah, J., 


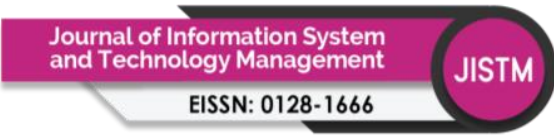

Volume 6 Issue 22 (September 2021) PP. 115-127 DOI: 10.35631/JISTM.622010

Wahiza, W., Nazlena, M.A., Fauzanita K., Azlina, A.A., Puteri Nor Ellyza, N., Ahmad Hanif, A.B., Mohamad Taha, I., Rabiah, A. K., Norshita M.N., Ummul Hanan, M., Ely Salwana M.S. \& Mohammad Nazir Ahmad @ Sharif. (2016). Integrating Computational Thinking (CT) With English Across STEM: Proposal. Bangi: Universiti Kebangsaan Malaysia (Unpublished).

Hurd, P. (2018). The State of Critical Thinking Today. New York: Organiser in Developing Blueprints for Instititional Change Foundation for Critical Change.

Kong, S. \& Abelson, H. (2019). Computational Thinking Education. Computational Thinking Education

Kong, S.C., Chiu, M.M. \& Lai, M. (2018). A Study Of Primary School Students' Interest, Collaboration Attitude and Programming Empowerment in Computational Thinking Education. Computers And Education 127:178-189. https://doi.org/10.1016/j.compedu.2018.08.026.

Lu, J.J. \& Fletcher, G.H.L. (2009). Thinking About Computational Thinking Categories and Subject Descriptors. Sigcse 260-264. http://doi.org/10.1145/1539024.1508959

McKillip, J. (1987). Need analysis: Tools for the human service and education. Applied Social Research Methods Series, 10. Sage Publications: Thousand Oaks, CA.

Mohd Shukri, A.A., Che Ahmad, C.N. \& Daud, N. (2019.) Implementing a Celik STEM Module in Empowering Eighth-Graders' Creative Thinking. International Journal of Education, Psychology and Counseling 4(32): 219-237.

Norzari, A.Y. \& Saimian, H. (2014). The Effects of Problem-Solving Teaching on Creative Thinking among District 2 High School Students in Sari City. Journal of the Academy of Medical Sciences of Bosnia \& Herzegovina, 26(6): 360-363.

Pérez-Marín, D., Hijón-Neira, R., Bacelo, A. \& Pizarro, C. (2018). Can Computational Thinking Be Improved by Using a Methodology Based on Metaphors and Scratch to Teach Computer Programming to Children? Computers in Human Behavior

Reviere, R., Berkowitz, S., Carter, C.C., \& Gergusan, C. G. (Eds). (1996). Need Assessment: A Creative and Practical Guide for Social Scientists. Taylor and Francis: Washington, DC.

Robbie, C.J.M.C., Ginns, I.A.N.S. \& Stein, S.J. (2000). Preservice Primary Teachers' Thinking About Technology and Technology Education (d): 81-101.

S Amri, C W Budiyanto \& R A Yuana. (2019). Beyond Computational Thinking: Investigating CT Roles in the 21st Century Skill Efficacy. The 2nd International Conference on Science, Mathematics, Environment, and Education. https://doi.org/10.1063/1.5139735

Selby, C. (2013). Computational Thinking: The Developing Definition. ITiCSE Conference $20135-8$.

Shanmugam, L., Yassin, S.F. \& Khalid, F. (2019). Incorporating The Elements of Computational Thinking into The Mobile Application Development Life Cycle (MADLC) Model. International Journal of Engineering and Advanced Technology 8(5): 815-824.

Sung, W., Ahn, J. \& Black, J.B. (2017). Introducing Computational Thinking to Young Learners: Practicing Computational Perspectives Through Embodiment in Mathematics Education. Technology, Knowledge and Learning 22(3): 443-463.

Sullenger, K. (2005). Fostering Higher Level of Scientific Literacy: Confronting Potential Barriers to Science Understanding. New Brunswick: University of New Brunswick 
Volume 6 Issue 22 (September 2021) PP. 115-127 DOI: 10.35631/JISTM.622010

Tsingos-Lucas, C., Sinthia Bosnic-Anticevich,Carl R. Schneider, \& Lorraine Smith. (2016). The Effect of Reflective Activities on Reflective Thinking Ability in an Undergraduate Pharmacy Curriculum. American Journal of Pharmaceutical Education. 80(4): 65.

Voogt, J., Fisser, P., Good, J., Mishra, P. \& Yadav, A. (2015). Computational Thinking in Compulsory Education: Towards an Agenda for Research and Practice. Education and Information Technologies 20(4): 715-728. http://doi.org/10.1007/s10639-015-9412-6

Wing, J. (2006). Computational thinking. Communications of the ACM, 49(3), 33-35.

Wing, J.M. (2008). Computational Thinking and Thinking About Computing. Philosophical Transactions of the Royal Society A: Mathematical, Physical and Engineering Sciences 366 (1991): 3717-3725

Wing, J. M. (2011). Research Notebook: Computational Thinking - What and Why? The Link. Pittsburg: Carnegie Mellon.

Yadav, A., Hong, H. \& Stephenson, C. (2016). Computational Thinking for All: Pedagogical Approaches to Embedding 21st Century Problem Solving in K-12 Classrooms 565568. https://doi.org/10.1007/978-3-319-52691-1

Zahilah Mohamed Zaki, F., Wong, S.L. \& Ridzwan Yaakub, M. (2019). A Review of Common Features in Computational Thinking Frameworks in K-12 Education. IOP Conference Series: Materials Science and Engineering 551(1) 